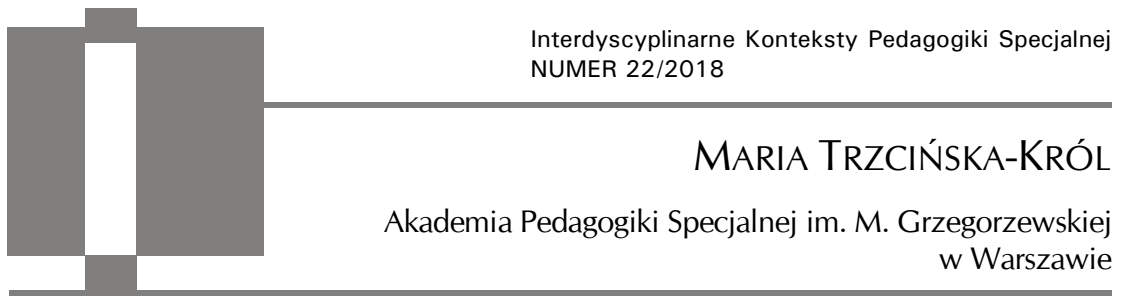

\title{
Senior w świecie mediów
}

ABSTRACT: Maria Trzcińska-Król, Senior w świecie mediów [Seniors in the media world]. Interdyscyplinarne Konteksty Pedagogiki Specjalnej, nr 22, Poznań 2018. Pp. 51-71. Adam Mickiewicz University Press. ISSN 2300-391X. DOI: https://doi.org/10.14746/ ikps.2018.22.04

Nowadays, the media education process begins at a very early stage of life and lasts throughout life. Older people are still in a worse position in this respect. In order to find a place in the information society, they have to master the IT and media skills and competences that allow not only to use new forms of education (e.g. e-learning, distance learning, blended learning), but also to an ever greater extent to handle everyday affairs. (e.g. making a payment, booking a ticket, settling a case at the office). The key role is played by education, computer and internet training and non-institutional support. Among the most frequently cited reasons for not using technology, researchers mention the lack of: motivation; access to media, the Internet; competence; awareness of how, for what use ICT can be used. The main obstacles in the dissemination of new technologies to the public are not hard barriers, like lack of infrastructure or financial constraints, but soft, related to the lack of: knowledge, conscious needs or skills.

KEY WORDS: media, new technologies, ICT, skills, competition, old people, senior

\section{Wprowadzenie}

W dzisiejszych czasach proces edukacji medialnej rozpoczyna się na bardzo wczesnym etapie i trwa przez całe życie. Osoby starsze w dalszym ciągu pod tym względem sytuują się na gorszej po- 
zycji. Chcąc się odnaleźć w społeczeństwie informacyjnym, muszą opanować umiejętności i kompetencje informatyczno-medialne, które pozwalają nie tylko na korzystanie $\mathrm{z}$ nowych form edukacji (np.: e-learning, distance learning, blended learning), ale także w coraz większym zakresie umożliwiają załatwienie spraw codziennych (np.: dokonanie płatności, rezerwacji biletu, załatwienie sprawy w urzędzie bez konieczności wystawania w długich kolejkach) czy chociażby komunikację z innymi osobami. Należy podkreślić, że „brak kompetencji w zakresie korzystania negatywnie koreluje z chęcią potencjalnych nowych użytkowników do zainteresowania się technologiami"1. Kluczową rolę odgrywa edukacja, szkolenia z zakresu obsługi komputera i internetu oraz pozainstytucjonalne wsparcie. Wśród najczęściej wymienianych przyczyn nie korzystania $\mathrm{z}$ technologii badacze wymieniają bark: motywacji; dostępu do mediów, internetu; kompetencji; świadomości tego w jaki sposób, na jaki użytek można wykorzystać ICT (ang. information and communication technology - technologie informacyjno-komunikacyjne). Głównymi przeszkodami w upowszechnianiu nowych technologii wśród społeczeństwa nie są bariery twarde, tj. brak infrastruktury czy ograniczenia finansowe, lecz miękkie, związane z brakiem: wiedzy, uświadomionych potrzeb czy umiejętności². „Nowe technologie stały się podstawowym ogniwem rozwoju młodego pokolenia..."3, a jak w nowej rzeczywistości społecznej odnajduje się osoba starsza? Jakie problemy i możliwości pojawiają się

${ }^{1}$ K. Stachura, Wymiary cyfrowych nierówności. Uwagi o problemie technologicznej nieobecności, [w:] Nieobecność społeczna. W poszukiwaniu sensów i znaczeń, red. Z. Galor, B. Goryńska-Bittner, Wydawnictwo Wyższej Szkoły Nauk Humanistycznych i Dziennikarstwa w Poznaniu, Poznań 2012, s. 264.

2 D. Batorski, Technologie i media w domach i w życiu [w:] Diagnoza społeczna 2015. Warunki i jakość życia Polaków, red. J. Czapiński, T. Panek, Rada Monitoringu Społecznego, Warszawa 2015, s. 373-395, http://www.diagnoza.com/pliki/raporty/ Diagnoza_raport_2015.pdf [dostęp: 13.06.2018].

${ }^{3}$ K. Wasilewska, Zaangażowanie seniorów w zakresie technologii informacyjno-komunikacyjnych na tle umiejętności młodszego pokolenia. "Zeszyty Naukowe Wydziału Elektroniki i Informatyki Politechniki Koszalińskiej” 2015, nr 7, s. 101. 
przed seniorami $\mathrm{w}$ związku $\mathrm{z}$ użytkowaniem nowych technologii? Jakie działania edukacyjne $w$ zakresie obsługi narzędzi ICT podejmowane są na rzecz osób starszych? Na ile nowe technologie są dostosowane do potrzeb seniorów? Poszukując odpowiedzi na te pytania została dokona analiza dostępnej literatury i wyników badań związanych z wykorzystaniem narzędzi ICT przez osoby starsze.

\section{Zmiany zachodzące w obrębie społeczeństw}

Zmiany technologiczne, które dokonują się w obrębie społeczeństw, uczeni starają się opisać takimi pojęciami, jak: społeczeństwo sieci ${ }^{4}$, społeczeństwo informacyjne ${ }^{5}$, społeczeństwo wiedzy ${ }^{6}$, społeczeństwo postprzemysłowe, postindustrialne ${ }^{7}$, ponowoczesność 8 , późna nowoczesność 9 , druga nowoczesność, społeczeństwo ryzyka ${ }^{10}$, trzecia fala ${ }^{11}$. Innym bardzo ważnym aspektem przeobrażeń są przemiany demograficzne, transformacja struktury wiekowej populacji, które determinują wiele zmian zachodzących w społe-

${ }^{4}$ M. Castells, The Rise of the Network Society, 1996, wyd. pol.: Spoteczeństwo sieci, Wydawnictwo Naukowe PWN, Warszawa 2008.

${ }^{5}$ T. Goban-Klas, P. Sienkiewicz, Społeczeństwo informacyjne: szanse, zagrożenia, wyzwania, Wydawnictwo Postępu Telekomunikacji, Kraków 1999, http://informacja cyfrowa.wsb.edu.pl/pdfs/SpoleczenstwoInformacyjne.pdf [dostęp: 3.07.2015]; S. Juszczyk, Człowiek w świecie elektronicznych mediów - szanse i zagrożenia, Wydawnictwo Uniwersytetu Śląskiego, Katowice 2000.

${ }^{6}$ P.F. Drucker, Myśli przewodnie Druckera, Wydawnictwo MT Biznes, Warszawa 2002.

${ }^{7}$ A. Touraine, The Post-Industrial Society. Tomorrow's Social History: Classes, Confl icts and Culture in the Programmed Society, Random House, New York 1971; D. Bell, The Coming of Post-Industrial Society, Basic Books, New York 1973.

8 Z. Bauman, Liquid Modernity, Polity Press, Cambridge 2000; wyd. pol.: Ptynna nowoczesność, Wydawnictwo Literackie, Kraków 2006.

${ }^{9} \mathrm{~A}$. Giddens, Nowoczesność $i$ tożsamość. "Ja" $i$ społeczeństwo w epoce późnej nowoczesności, Wydawnictwo Naukowe PWN, Warszawa 2001.

${ }^{10}$ U. Beck, E. Grande, Europa Kosmopolityczna. Społeczeństwo i polityka w drugiej nowoczesności, Wydawnictwo Naukowe Scholar, Warszawa 2009.

${ }^{11}$ A. Toffler, The third wave, Bantam Books, New York 1980. 
czeństwach oraz podejmowanych działań. Pokolenie urodzone w latach 1961-1984 nazywane jest pokoleniem X i funkcjonującym w świecie mediów, nazywanych przez Marshalla McLuhana madiami gorącymi tj. prasy, radia, telewizji. Z kolei pokolenie urodzone w latach 1977-1997) nazywane jest generacją $Y$ i funkcjonuje głównie w świecie komputerów, Internetu Web 1.0, czyli charakteryzują się nikłym wykorzystaniem narzędzi umożliwiających generowanie własnych treści $\mathrm{w}$ sieci (np. czytaniem i komentowaniem blogów, dyskusjami na forach, udziałem w grupach dyskusyjnych, promocją własnej działalności w Sieci). Pokolenie Z, to pokolenie ludzi urodzonych w latach 1995-2010, a ich świat zdominowany jest przez portale społecznościowe, komórki, gry internetowe i Internet Web 2.0. Osoby urodzone po 2010 r. nazywane są generacją Alfa, funkcjonujące w świecie elektronicznych gadżetów, smartfonów ${ }^{12}$. „Jest to jedno z pierwszych pokolen, które doświadcza nowego - bo opartego na technologiach - systemu wychowania, edukacji, zabawy oraz rozrywki"13. Świat nowych technologii jest w ich życiu obecny od urodzenia i jest rzeczą tak naturalną, jak dla seniorów papierowe wydania książki, prasy czy pisanie tradycyjnych listów.

Grupa seniorów z roku na rok stanowi coraz większą subpopulację. Według danych GUS-u liczba ta w latach 2000-2017 w Polsce zwiększyła się ona o ponad 2,3 $\mathrm{mln}^{14}$. „Fakt, że żyjemy dłużej i w lepszym zdrowiu to duży sukces współczesnego społeczeństwa"15,

12 M. Gruchoła, Nowe formy zachowań społecznych wobec i pod wptywem mediów oraz nowych technologii. Analizy porównawcze, „Państwo i Społeczeństwo” 2017, t. XVII, nr 3, s. 123-133.

13 Ibidem, s. 132.

14 Ludność. Stan i struktura oraz ruch naturalny w przekroju terytorialnym w 2017 r. Stan w dniu 31 XII, Główny Urząd Statystyczny, Warszawa 2018, https://stat. gov.pl/obszary-tematyczne/ludnosc/ludnosc/ludnosc-stan-i-struktura-oraz-ruchnaturalny-w-przekroju-terytorialnym-w-2017-r-stan-w-dniu-31-xii,6,23.html [dostęp: 21.05.2018].

15 M. Ferry, R. Baker, Strategie regionalne a starzenie się społeczeństwa, Komitet Regionów-Age Concern England, Bruksela 2006, s. 2, http://ec.europa.eu/regional_ policy/archive/conferences/demographicchallenge_jan07/doc/presentations/age proofing_toolkit_pl.pdf [dostęp: 21.05.2018]. 
a zarazem stanowi duże wyzwanie, nie tylko dla polityki społecznej, ale także dla medycyny, farmakologii, pedagogiki. Zmiany stylu życia, wzorców zachowań, relacji czy komunikacji osób starszych otwierają przed nimi nowe możliwości, ale także potrzebę ciągłego kształcenia m.in. w zakresie nowych technologii. W społeczeństwie informacyjnym ważnym „aspektem jest [...] kształcenie społeczeństwa w kierunku dalszego rozwoju, tak by wszyscy mogli w pełni wykorzystywać możliwości, jakie dają środki masowej komunikacji $\mathrm{i}$ informacji" 16 .

Pokolenie seniorów nazywane jest pokoleniem Cyfrowych Imigrantów, osób, które trafiły do epoki cyfrowo-komputerowej jako dorośli. Niejednokrotnie towarzyszyły temu duże obawy i niepewność. Nie dlatego, że nie potrzebują ułatwień, użytkowania najnowszych technologii, ale dlatego, że są one dla nich nowością, której trzeba się nauczyć, która burzy tradycyjny, dotychczasowy sposób ich funkcjonowania. Taka zamiana wymaga czasu i wypracowania nowych schematów działania ${ }^{17}$. Często trudno jest im odnaleźć się w środowisku ICT, w społeczeństwie, gdzie umiejętność dotarcia do informacji, gromadzenia jej i przetwarzania stały się wartościami nadrzędnymi.

\section{Wykorzystanie narzędzi ICT przez seniorów}

Jednym z głównych wskaźników dostępu do technologii w dalszym ciągu jest wiek ich użytkowników. Jak pokazują badania, grupą najbardziej wykluczoną są osoby powyżej 55. roku życia, a w szczególności powyżej 65. roku życia. W 2017 r. wśród grupy

16 Definicja pochodzi ze stron internetowych Urzędu Komitetu Integracji Europejskiej: http://archiwum-ukie.polskawue.gov.pl/www/serce.nsf/0/6A1F328341480 FEAC1256F6A0038762F?Open oraz jest używana w regulaminach konkursów w definiowaniu terminu społeczeństwa informacyjnego $\mathrm{w}$ projektach wdrażanych przez Centrum Projektów Polska Cyfrowa.

17 G. Small, G. Vorgan, iMózg. Jak przetrwać technologiczna przemianę współczesnej umysłowości, Vesper, Poznań 2011. 
wiekowej 55-64 lata osoby regularnie korzystające z komputera stanowiły $46,8 \%$ badanych, a wśród $65-77$ lat tylko $25,6 \%$ osób. Zamawiający lub robiący zakupy przez internet $\mathrm{w}$ grupie wiekowej 55-64 lata to $19,6 \%$ badanych, a grupie wiekowej 65-74 lata tylko $8,6 \%$. Jeśli zaś chodzi o umiejętności cyfrowe związane z korzystaniem z komputera, tylko 20,2\% osób w wieku 55-64 lat potrafiło przenosić pliki pomiędzy komputerem a innym urządzeniem i tylko 9,4\% w wieku 65-74 lat. Zmieniać ustawienie dowolnego programu operacyjnego lub programów zapewniających bezpieczeństwo urządzeń potrafiło 10,1\% badanych w wieku 55-64 i tylko 4,7\% w wieku 65-74 lat. Jeszcze mniejszy odsetek badanych w tych grupach respondentów potrafił instalować oprogramowanie lub aplikacje na urządzeniach $\left(9,6 \%\right.$ - 55-64 lat; 4,7\% - 65-74 lat) ${ }^{18}$. Osoby żyjące w Polsce spędzają przeciętnie cztery godzinny dziennie na korzystanie z różnych mediów. Czas ten rozdysponowany jest pomiędzy media: prasę, radio, telewizję, internet i mocno związany jest z wiekiem. Osoby starsze w dalszym ciągu preferują oglądanie telewizji (im osoba starsza tym więcej czasu poświęca w ciągu dnia spędza przed telewizorem), a osoby młodsze korzystanie z internetu. Osoby w przedziel wiekowym do 24 lat deklarowały największy zakres czasowy, jaki poświęcały na użytkowanie internetu. I choć jak widać na wykresie 1., czytelnictwo prasy jest mało zróżnicowane, to jednak seniorzy poświęcają więcej czasu w ciągu dnia na tę czynność 19 .

Liczba użytkowników internetu, z roku na rok systematycznie wzrasta w każdej grupie wiekowej. W 2015 r. co czwarty emeryt i mniej więcej co trzeci rencista korzystał z internetu. Wart podkreślenia jest fakt, że w przeciągu dwóch lat (2013-2015) w grupie wiekowej 60-64 lata zaobserwowano 5,3\% wzrost użytkowników,

18 Społeczeństwo informacyjne w Polsce. Wyniki badań statystycznych z lat 2013-2017, Główny Urząd Statystyczny, Warszawa-Szczecin 2017, http://stat.gov.pl/obszarytematyczne/nauka-i-technika-spoleczenstwo-informacyjne/spoleczenstwo-informa cyjne/spoleczenstwo-informacyjne-w-polsce-wyniki-badan-statystycznych-z-lat-20132017,1,11.html [dostęp: 13.06.2018].

19 D. Batorski, op. cit., s. 390. 


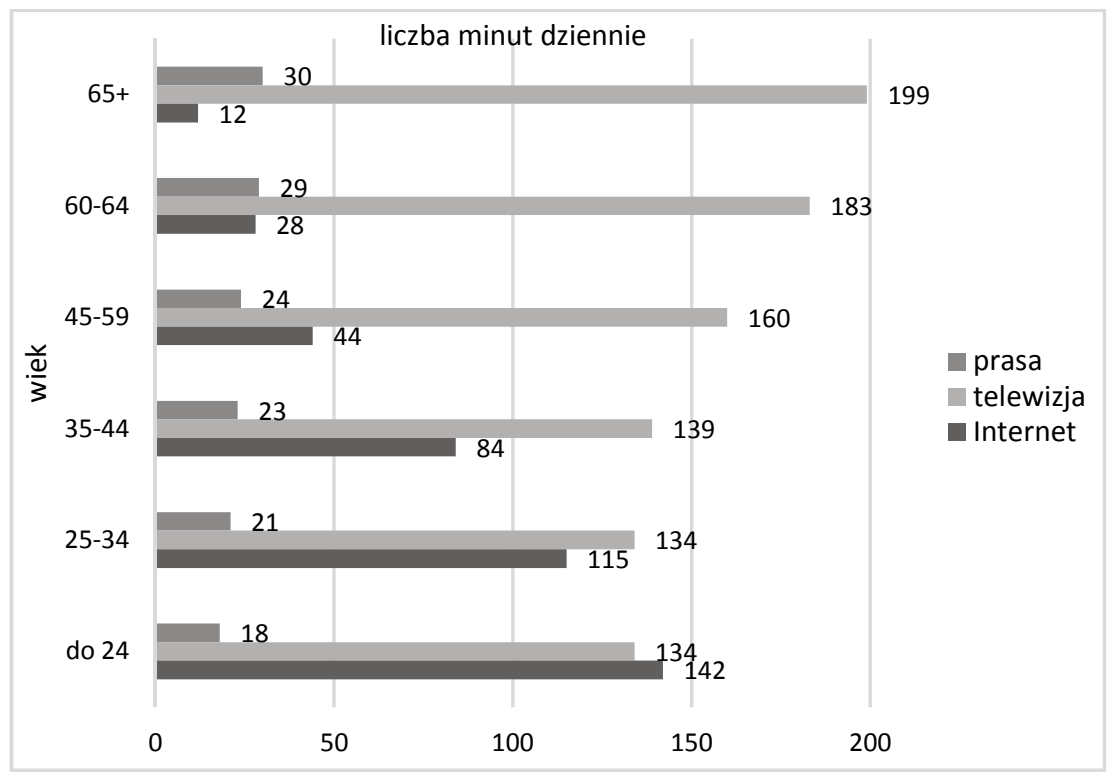

Wykres 1. Czas poświęcony w ciągu dnia przez respondentów na czytanie pracy, oglądanie telewizji, użytkowanie internetu w 2015 r.

Źródło: D. Batorski, Technologie i media w domach i w życiu Polaków, [w:] Diagnoza społeczna 2015. Warunki i jakość życia Polaków, red. J. Czapiński, T. Panek, Rada Monitoringu Społecznego, Warszawa 2015, s. 390

a w grupie powyżej 65. roku życia 3,8\% wzrost $^{20}$. Z kolei badania NBP ukazują, że niespełna $3 \%$ seniorów deklaruje użytkowanie bankowości mobilnej. PKO BP podaje, że z bankowości mobilnej IKO korzysta $2 \%$ osób w wieku powyżej 65 . roku życia oraz $5 \% \mathrm{w}$ wieku 55-64 lat ${ }^{21}$.

Badania Komisji Europejskiej Indeksu cyfrowej gospodarki i społeczeństwa (DESI) pokazują, że tylko 44\% Polaków posiada pod-

${ }^{20}$ D. Batorski, op. cit., s. 373-395.

${ }^{21}$ M. Bednarek, Zagubiony senior w bankowości mobilnej. Specjalne infolinie w Orange i doradcy w PKO, „Wyborcza” 2017, 23 czerwca, http://wyborcza.biz/biznes/7,158 582,21998635,zagubiony-senior-w-swiecie-bankowosci-mobilnej-specjalne-infolinie.html [dostęp: 18.06.2018]. 
stawowe kompetencje cyfrowe, do których zaliczana są: umiejętność korzystania $\mathrm{z}$ narzędzi biurowych, poczty elektronicznej czy komunikatorów internetowych. Zwraca także uwagę na fakt, że osoby o niskim wykształceniu lub o niskich dochodach oraz osoby starsze, emerytowane lub bierne zawodowo, są mniej aktywnymi użytkownikami internetu. I chociaż wskaźniki korzystania z sieci wśród tych grup rosną, to w każdej z nich 4 na 10 osób nie korzysta z niej regularnie. Oznacza to, że ryzyko wykluczenia cyfrowego w tej grupie jest szczególnie wysokie 22 .

Niemal pod każdym względem, jeśli chodzi o umiejętności cyfrowe, najlepiej w badaniach wypadają osoby w wieku 17-24 lata23.

Tabela 2. Obsługa komputera - badania PIAAC

\begin{tabular}{|c|c|c|c|c|}
\hline Wiek & $\begin{array}{c}\text { Brak doświadczenia } \\
\text { w obsłudze kompu- } \\
\text { tera (deklaracja } \\
\text { badanych osób) }\end{array}$ & $\begin{array}{c}\text { Brak podstawowych } \\
\text { umiejętności obsługi } \\
\text { komputera mimo dekla- } \\
\text { racji korzystania z niego } \\
\text { (nie zaliczony test pod- } \\
\text { staw obsługi komputera) }\end{array}$ & $\begin{array}{c}\text { Brak informacji } \\
\text { o poziomie znajomości } \\
\text { obsługi komputera } \\
\text { (odmowa rozwiązy- } \\
\text { wania komputerowej } \\
\text { wersji zadań) }\end{array}$ & $\begin{array}{c}\text { Dostateczna znajo- } \\
\text { mość obsługi kompu- } \\
\text { tera (pozwalająca } \\
\text { na rozwiązywanie } \\
\text { komputerowej wersji } \\
\text { zadań) }\end{array}$ \\
\hline $16-24$ & $1 \%$ & $19 \%$ & $9 \%$ & $28 \%$ \\
\hline $25-34$ & $4 \%$ & $22 \%$ & $19 \%$ & $33 \%$ \\
\hline $35-44$ & $13 \%$ & $21 \%$ & $22 \%$ & $19 \%$ \\
\hline $45-54$ & $32 \%$ & $19 \%$ & $25 \%$ & $12 \%$ \\
\hline $55-65$ & $50 \%$ & $20 \%$ & $25 \%$ & $7 \%$ \\
\hline
\end{tabular}

Źródło: M. Palczyńska, Wykorzystanie technologii informacyjno-komunikacyjnych, [w:] Umiejętności Polaków - wyniki Międzynarodowego Badania Kompetencji Osób Dorostych (PIAAC), Warszawa 2013, s. 118

${ }^{22}$ Human Capital - Digital Inclusion and Skills, Digital Economy and Society Index Report 2018, Human Capital, http:/ / ec.europa.eu/newsroom/dae/document. cfm?doc_id=52247 [dostęp: 12.10.2018].

23 Społeczeństwo informacyjne w Polsce. Wyniki badań statystycznych z lat 2013-2017, Główny Urząd Statystyczny, Warszawa-Szczecin 2017, http:/ / stat.gov.pl/obszarytematyczne/nauka-i-technika-spoleczenstwo-informacyjne/spoleczenstwo-informa cyjne/spoleczenstwo-informacyjne-w-polsce-wyniki-badan-statystycznych-z-lat-20132017,1,11.html [dostęp: 13.06.2018]. 
Badania PIAAC pokazują, że 82\% badanych deklarowało brak doświadczenia w obsłudze komputera i były to osoby w wieku 45-65 lat, a tylko $1 \%$ wśród osób poniżej 24 . roku życia. Niespełna $7 \%$ badanych w wieku 55-65 lat wykazywało się dostateczna znajomością obsługi komputera pozwalającą na rozwiązanie zadań w wersji komputerowej. Najlepiej w tej kategorii wypadły osoby w przedziale wiekowym 25-34 lata (tabela 2). Głównym wskaźnikiem nie tylko dostępu do technologii, ale i doświadczenia w jego obsłudze w dalszym ciągu jest wiek ich użytkowników.

Preferencje wyboru klasycznych źródeł informacji, tj. książki, prasy, radia, telewizji wśród osób starszych potwierdzają nie tylko

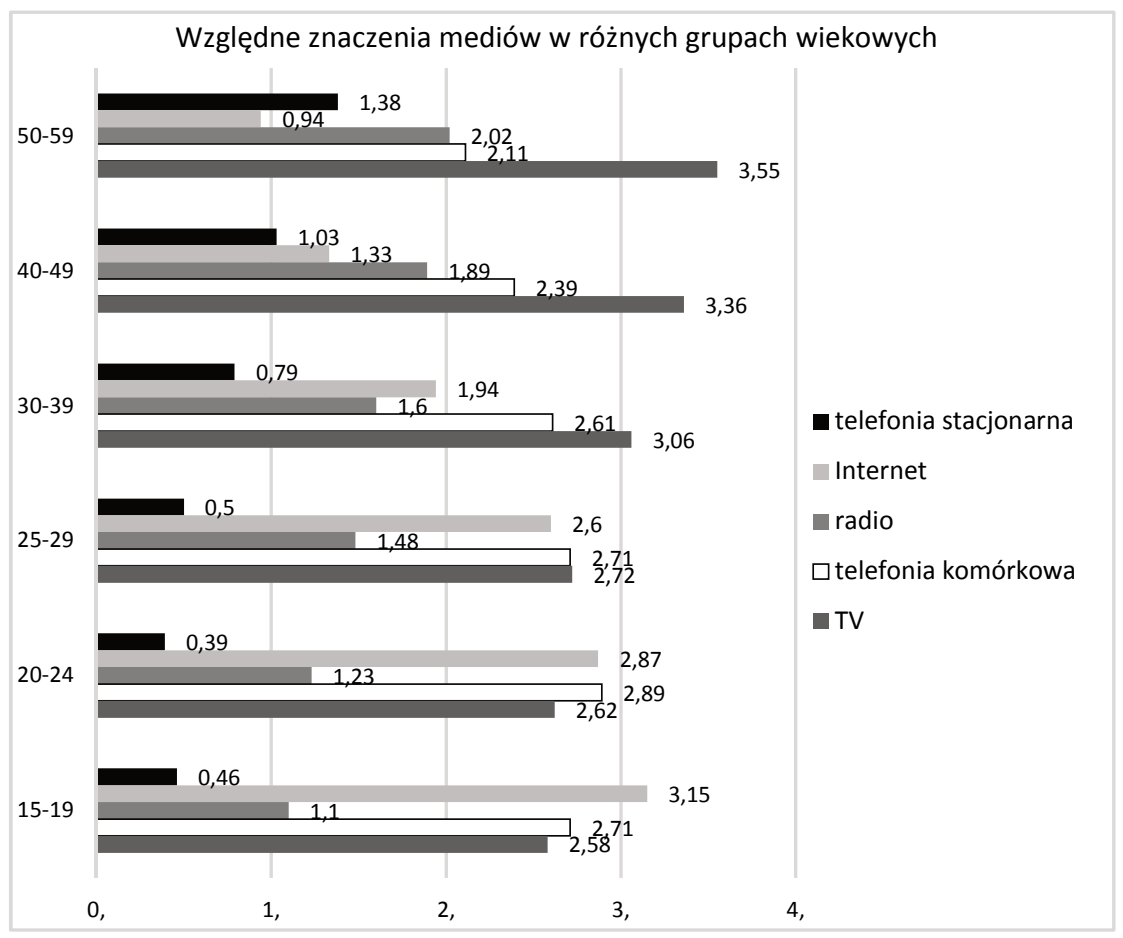

Wykres 2. Znaczenie mediów w różnych grupach wiekowych

Źródło: opracowanie własne na podstawie World Internet Project Poland 2012 
badania World Internet Project (wykres 2), ale także badania diagnozy społecznej zrealizowanych trzy lata później (wykres 3). Dla osób starszych zdecydowanie największe znaczenie ma przekaz telewizyjny, a im młodsza osoba, tym większy nacisk kładzie na korzystanie $\mathrm{z}$ internetu.

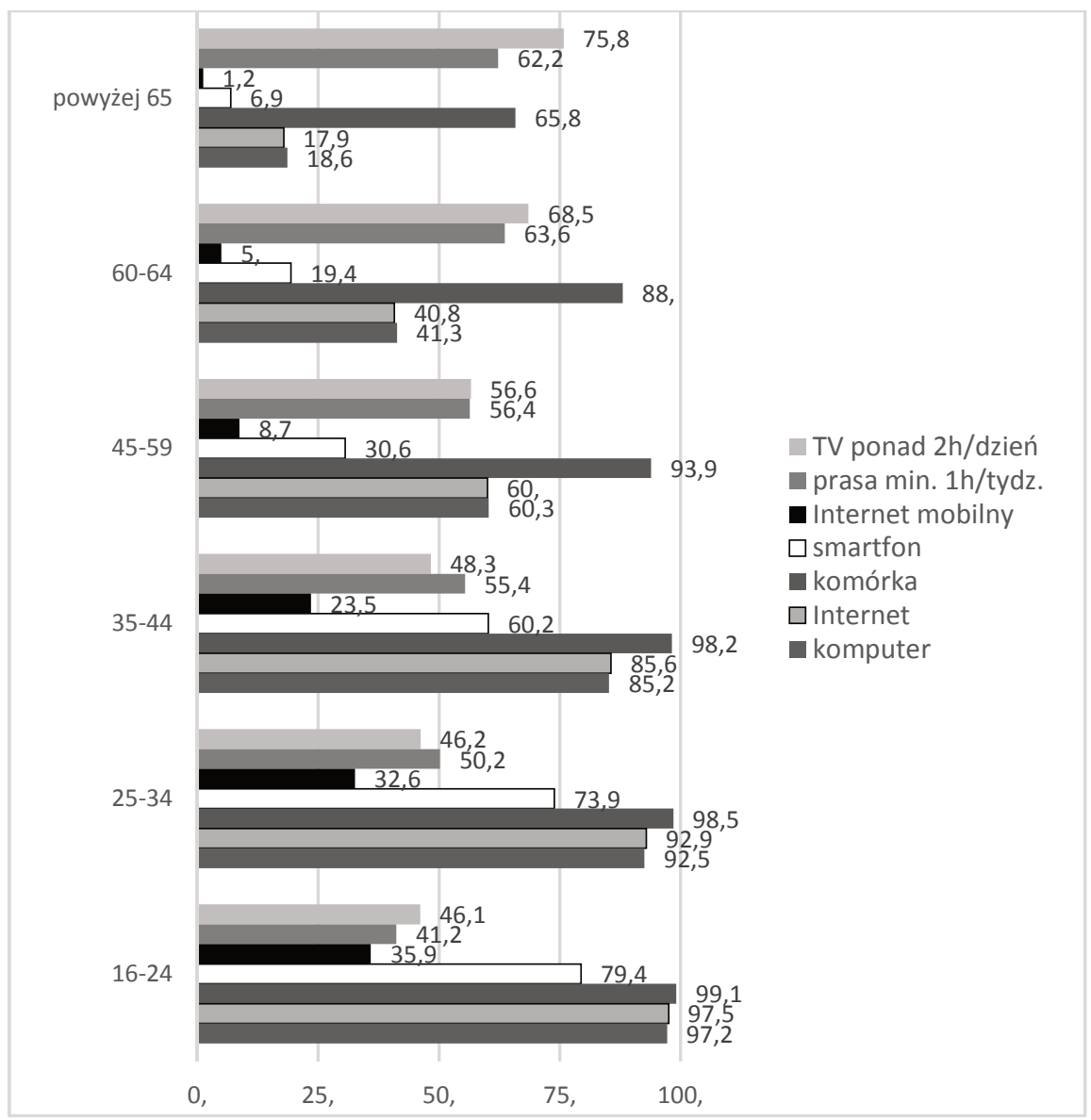

Wykres 3. Korzystanie z technologii i mediów w różnych grupach wiekowych

Źródło: D. Batorski, Technologie i media w domach i w życiu Polaków, [w:] Diagnoza społeczna 2015. Warunki i jakość życia Polaków, red. J. Czapiński, T. Panek, Warszawa 2015, s. 383 
W badaniach diagnozy społecznej dodatkowo zostało wyróżnione użytkowanie komputera i smartfonu. Jednak i w tym przypadku widoczna jest mocna tendencja do użytkowania nowych technologii przez osoby młodsze. Wśród starszych jest to prasa i telewizja, choć także można zauważyć silną tendencję do korzystania z telefonów komórkowych.

Pomimo wciąż rosnącej liczby seniorów korzystających z internetu i nowych technologii, w dalszym ciągu są oni grupą najbardziej zagrożoną wykluczeniem cyfrowym. Należy także zauważyć, że osoby starsze korzystające $\mathrm{z}$ narzędzi ICT traktują je jako narzędzia ułatwiające pracę, życie, a nie tak jak ma to miejsce w przypadku osób młodych - jako równoprawną rzeczywistość ${ }^{24}$.

\section{Bariery miękkie w wykorzystaniu narzędzi ICT przez seniorów}

Jan van Dijk wyodrębnił następujące typy dostępu do nowych technologii: motywacyjny, użytkowy, kompetencyjny oraz materialny i fizyczny ${ }^{25}$. Jak pokazują badania przeprowadzone wśród osób starszych, problemy w korzystaniu $\mathrm{z}$ nowych technologii związane są z aspektem motywacyjnym i kompetencyjnym ${ }^{26}$. Osoby starsze podchodzą do nowych technologii z nieufnością

${ }^{24}$ K. Barani, M. Hołda, Osobowość i jakość życia, a korzystanie z Internetu przez seniorów, [w:] Senior zalogowany, red. B. Szmgielska, Wydawnictwo Uniwersytetu Jagiellońskiego, Kraków 2014, za: J. Gacka, Polscy seniorzy w sieci: wirtualna złota jesień? Korzystanie przez osoby dojrzałe z internetu $i$ nowych technologii, „Konteksty Społeczne" 2017, 1(9), s. 87.

25 J. Dijk, Społeczne aspekty nowych mediów, Wydawnictwo Naukowe PWN, Warszawa 2010, za: A. Niemczyk, Seniorzy wobec nowych technologii, „Studia Ekonomiczne. Zeszyty Naukowe Uniwersytetu Ekonomicznego w Katowicach" 2016, nr 303, s. 102-113.

${ }^{26}$ Porównaj m.in.: D. Batorski, op. cit.; M. Mucha, Demograficzne uwarunkowania konsumpcji - seniorzy na rynku dóbr i ustug w Polsce, "Prace Naukowe Uniwersytetu Ekonomicznego we Wrocławiu" 2017, nr 501, s. 87-95; T. Zalega, Konsumpcja osób starszych w Polsce, „Nierówności Społeczne a Wzrost Gospodarczy” 2015, nr 42 
korzystając z nich w sposób analogiczny do dotychczasowego użytkowania wcześniej posiadanych urządzeń (np. telefonu), gorzej poruszają się w świecie wirtualnego przekazu, przedkładają treści tekstowe nad multimedia, preferują myślenie linearne i szeregowe przetwarzanie informacji oraz lepiej rozumieją dłuższe treści ${ }^{27}$.

Seniorzy nie są w stanie osiągnąć takiej biegłości w obsłudze mediów jak młodzież. Wiele opcji, zastosowań ICT nie jest dostosowanych do ich potrzeb i możliwości. Często też odczuwają strach, dyskomfort, obawy przed ich użytkowaniem: Czy sobie poradzą? Czy nie popsują? Bardzo często nawet obsługa telefonu komórkowego przerasta ich możliwości i potrzebują pomocy osób trzecich. Strach przed użytkowaniem nowych technologii według Natalii Bojarskiej i Moniki Dawidowskiej może wynikać z tego, że seniorzy

nie będą w stanie zapamiętać koniecznych do poruszania się w alternatywnej dla nich rzeczywistości informacji. Można odnieść wrażenie, że oddają pole do popisu młodszym od siebie, bo to pokolenie swoich dzieci i wnuków uznają za właściwych użytkowników nowej technologii. Są skłonni uważać, że poradzą sobie bez Internetu, bo na jego rozpoznaniu - takim, które umożliwiłoby dalszy, satysfakcjonujący użytek - więcej tracą, niż zyskują28.

Kompetencje informatyczno-medialne dają duże możliwości w kierowaniu własnym rozwojem, dają szansę na dostęp do infor-

(2/2015), s. 152-173; Społeczeństwo informacyjne w Polsce. Wyniki badań statystycznych z lat 2013-2017, Główny Urząd Statystyczny, Warszawa - Szczecin 2017, http:/ / stat. gov.pl/obszary-tematyczne/nauka-i-technika-spoleczenstwo-informacyjne/spoleczen stwo-informacyjne/spoleczenstwo-informacyjne-w-polsce-wyniki-badan-statystycz nych-z-lat-2013-2017,1,11.html [dostęp: 13.06.2018].

27 J. Gacka, op. cit., s. 86.

${ }^{28}$ N. Bojarska, M. Dawidowska, Zamiast zakończenia. O zróżnicowaniu internetowego krajobrazu, [w:] W sieci i poza siecia. Typologia relacji $i$ strategie przystosowawcze wokót cyberprzestrzeni, red. K. Stachura, Wydawnictwo Uniwersytetu Gdańskiego, Gdańsk 2010, za: M. Szpunar, Senior w środowisku nowych mediów, [w:] Seniorzy $w$ świecie nowych technologii. Implikacje dla praktyki edukacyjnej oraz rozwoju społeczeństwa informacyjnego, red. Ł. Tomczyk, A. Wąsiński, „Biblioteka Gerontologii Społecznej" 2013, nr 1-2, s. 38. 
macji, wiedzy, samorozwoju. Jednak niejednokrotnie seniorzy sami wykluczają się z grona osób użytkujących nowe technologie poprzez rezygnację, przekonanie, że brak im odpowiednich umiejętności, kwalifikacji. Brak zainteresowania, obawa, strach towarzyszący sytuacjom wymagającym zdobycia nowej wiedzy i umiejętności, brak wiary we własne zdolności determinuje poczucie nieprzystosowania do życia w świecie zdominowanym przez technologie informacyjno-komunikacyjne. Późne podjęcie nauki obsługi tych narzędzi łączy się także z niską samooceną oraz tym, że bliscy często wyręczają go w wykonaniu wielu czynności, co skutkuje u niego brakiem wiary we własne umiejętności i możliwości rozwoju ${ }^{29}$. Osoby bez dostępu do ICT spotyka izolacja społeczna oraz zwiększenie dystansu społecznego. Lęk seniorów przed nowymi technologiami, zmianami opisywany jest przez wielu badaczy. Osoby starsze m.in. stwierdzają:

Ja się boję zmian. Długo byłam oporna na nowości, dlatego nie siadałam przy internecie. Każde coś nowego to się trochę boję, że znów nie będę wiedziała, że będę musiała się czegoś nauczyć.

Starsi ludzie są bardziej nerwowi, a więc zanim tam sobie wystukają, to już się zdenerwują.

Te nazwy, te wszystkie sposoby odszukiwania, to mnie absolutnie nie pociąga. Nie chciałabym się tego uczyć.

Wie pan, Olbrychski to nawet $\mathrm{z}$ telefonu nie korzysta, bo nie chce się uczyć30.

Najgorszy, najbardziej hamujący był strach przed tym, co nowe i lęk przed zepsuciem urządzenia ${ }^{31}$.

${ }^{29}$ A. Bąk, A. Jaszczak, Rzeczywiste kompetencje seniorów w zakresie korzystania z Internetu, [w:] Senior zalogowany, red. B. Szmigielska, Wydawnictwo Uniwersytetu Jagiellońskiego, Kraków 2014 za: J. Gacka, op. cit., s. 87.

30 J. Ambrosiewicz, I. Szylke, Społeczne, kulturowe i technologiczne uwarunkowania (nie)korzystania z Internetu, [w:] W sieci i poza siecia. Typologia relacji i strategie przystosowawcze wokót cyberprzestrzeni, red. K. Stachura, Wydawnictwo Uniwersytetu Gdańskiego, Gdańsk 2010, za: M. Szpunar, op. cit., s. 44. 


\section{Działania edukacyjne}

Kluczową rolę $\mathrm{w}$ działaniach o charakterze e-inkluzyjnym odgrywa edukacja, a kształcenie przez całe życie nabiera nowego znaczenia. Zmiany w sferze psychofizycznej seniorów utrudniają adaptację do nowości i uczenia się. Redukcja masy mózgu, degeneracja połączeń synaptycznych pociągają za sobą spowolnienie reakcji, wydłużenie czasu nauki, spowolnienie przyswajania nowości. Jednak jak pokazują badania Gary'ego Smalla32, wykonane przy pomocy tzw. funkcjonalnego magnetycznego rezonansu jądrowego, serfowanie po internecie $\mathrm{i}$ wyszukiwanie informacji $\mathrm{w}$ sieci tworzy nowe połączenia w mózgu u osób po 50. roku życia, co dowodzi, że nasz mózg jest zdolny do rozwoju nawet w podeszłym wieku. W ćwiczeniu mózgu oraz zapobieganiu jego procesom starzenia się amerykańscy naukowcy zalecają osobom starszym serfowanie po sieci, gdyż

przeszukiwanie Internetu za pomocą wyszukiwarek jest dla osób po 50. roku życia lepszą gimnastyką umysłu niż czytanie książek, a siła oddziaływania sieci jest porównywalna z układaniem puzzli lub rozwiązywaniem krzyżówek. Wynika to z tego, że proces decyzyjny podczas czytania książki jest zredukowany do dylematu: zamknąć ją czy kontynuować czytanie, podczas gdy w trakcie nawigowania w Internecie użytkownik nieustannie podejmuje decyzje o wyborze interesującej go informacji ${ }^{33}$.

Przez lata grupa seniorów była dyskryminowana w dostępnie do edukacji komputerowej i internetowej, a ich wiedza bazowała na informacjach od młodszych członków rodziny. Ostanie lata przyniosły wiele zmian związanych z edukacja osób starszych i uczenia się przez całe życie. Obecnie możliwość edukacji informatyczno-

${ }^{31}$ M. Sulik, Jesień życia kobiety - aspekty edukacyjne, [w:] Edukacja wobec starości tradycja i wspótczesność, red. A. Stopińska-Pająk, Uniwersytet Śląski, Katowice 2009, za: M. Szpunar, op. cit., s. 44.

32 G. Small, G. Vorgan, op. cit.

33 J. Morbitzer, Seniorzy w społeczeństwie informacyjnym, [w:] Seniorzy w świecie nowych technologii..., s. 26. 
-medialnej oferują nie tylko Uniwersytety Trzeciego Wieku, ale także biblioteki, organizacje pozarządowe, stowarzyszenia, fundacje. Podejmowanych jest wiele działań mających na celu edukację osób starszych. W ramach dotacji z funduszy rządowych, samorządowych, prywatnych czy też unijnych realizowane są bądź były projekty ukierunkowane na seniorów ${ }^{34}$. Organizowane są spotkania z osobami ze świata nauki, podczas których seniorzy mogą wysłuchać wystąpień na temat społeczeństwa informacyjnego, celowości użytkowania nowych technologii, bezpieczeństwa w cyberprzestrzeni. Są adresatami wielu publikacji książkowych oraz broszurowych poświęconych umiejętnościom użytkowania nowych technologii. Zachętą do nauki są takie czynniki jak: presja, silna potrzeba zdobycia informacji lub nawiązania kontaktu, ciekawość oraz wsparcie społeczne i świadomość możliwości, jakie dają nowe technologie ${ }^{35}$. Najistotniejszym aspektem korzystania z narządzi ICT jest motywacja ${ }^{36}$, wraz z którą pojawia się chęć zakupu odpo-

${ }^{34}$ Wśród działań ukierunkowanych na edukację informatyczno-medialną osób starszych można wymienić: „Cyfrowy Senior" - realizowany przez Chorągiew Kielecką Związku Harcerstwa Polskiego; „Akademia Bezpiecznego IT - równe szanse na rynku pracy" - realizowany przez akademie NASK wraz z Warszawska Wyższa Szkołą Informatyki; „Podaj dalej - Senior dla Kultury” - zrealizowany w 2014 r. i 2015 r. przez NASK; „Komputer i Internet dla seniora” - kurs komputerowy organizowany przez zespół Szkół Ponadgimnazjalnych nr 2 w Siedlcach; ,"ktywni 60+” - realizowany przez fundację Zaczyn $\mathrm{w}$ ramach projektów edukacji cyfrowej; "Ekompetencje bez barier" - realizowany przez Warmińsko-Mazurski Zakład Doskonalenia Zawodowego w Olsztynie w ramach Programu Operacyjnego Polska Cyfrowa. „Akademia E-seniora” zapoczątkowana w 2006 r. przez UPC Polska w ramach programu prospołecznego „W jednej społeczności”. To tylko nieliczne przykłady działań na rzecz podnoszenia kompetencji cyfrowych seniorów i przeciwdziałania wykluczeniu cyfrowemu.

${ }^{35} \mathrm{~K}$. Stachura, Wymiary cyfrowych nierówności. Uwagi o problemie technologicznej nieobecności, [w:] Nieobecność społeczna. W poszukiwaniu sensów i znaczeń, red. Z. Galor, B. Goryńska-Bittner, Wydawnictwo Wyższej Szkoły Nauk Humanistycznych i Dziennikarstwa w Poznaniu, Poznań 2012, s. 262-277.

${ }^{36} \mathrm{~W}$ latach 90. i na początku XXI w. głównym aspektem badań nad wykluczeniem cyfrowym był dostęp do infrastruktury, internetu, ograniczenia finansowe (tzw. bariery twarde). Obecnie uważa się, że ważniejsze od dostępu są umiejętności 
wiednich urządzeń. $\mathrm{W}$ wielu przypadkach skuteczną formą nauki obsługi narzędzi ICT jest edukacja, wsparcie ze strony najbliższych, niejednokrotnie wnuków. Jest to doskonała lekcja zarówno dla seniorów, którzy uczą się obsługi narzędzia, jak i dla wnuków, którzy uczą się cierpliwości i pokory. A co najważniejsze, jest to sposób na nawiązanie bliższych relacji międzypokoleniowych, możliwość poznania przez wnuki własnej historii opowiedzianej przez dziadków. Użytkowanie narzędzi ICT ma wiele korzyści dla każdej z grup wiekowych, a w przypadku seniorów internet, telefonia komórkowa pozwalają na komunikację z bliskimi. Ma to szczególne znaczenie $\mathrm{w}$ przypadku trudności z poruszaniem się osób w podeszłym wieku, choroby czy niepełnosprawności. Osłabienie dynamiki życiowej, szybsze męczenie się, pogorszenie motoryki, spowolnienie lub pogorszenie zwinności i gibkości niejednokrotnie powodują wycofanie się osób starszych z aktywnego życia. Internet pozwala im na wyszukanie informacji dotyczących opieki zdrowotnej, pomocy socjalnej, zagospodarowania czasu wolnego, znalezienia dodatkowej pracy, załatwienia spraw urzędowych bez konieczności wychodzenia z domu, zrobienie zakupów, czy chociażby porównania cen. Daje możliwość wyszukania w zaciszu domowym oferty kulturalnej, informacji na tematy ich interesujące. Umożliwia także na zredukowanie np. kosztów połączeń telefonicznych poprzez wykorzystywanie komunikatorów internetowych do kontaktów z bliskimi oraz uzyskanie połączenia z kilkoma osobami jednocześnie i wzbogaceniu go o obraz rozmówcy. Jest to niezwykle ważne przy niskich dochodach emerytów i ograniczeniach finansowych.

\section{Niedostosowanie narzędzi ICT do potrzeb osób starszych}

Seniorzy w kontakcie z nowymi technologiami napotykają wiele trudności. Jednym z głównych problemów są ograniczenia związa-

korzystania z narzędzi ICT, zdolność do czerpania zysków z ich użytkowania poprzez zwiększenie poczucia własnej niezależności (por. K. Stachura, op. cit.; D. Batorski, op. cit.; K. Polańska, op. cit.). 
ne $\mathrm{z}$ percepcją wzrokową oraz drżeniem rąk przy korzystaniu z klawiatury czy obsługi myszki. Zaprogramowanie kanałów telewizyjnych stanowi często barierę nie do pokonania i wymaga ingerencji osób trzecich. Postępująca miniaturyzacja, zawieranie coraz większej liczby możliwości w coraz mniejszym urządzeniu jest dla seniorów nie lada wyzwaniem. Ekrany dotykowe czy obsługa urządzeń głosem sprawiają trudności osobom w podeszłym wieku.

W dalszym ciągu ograniczeniami w użytkowaniu narzędzi ICT przez osoby starsze jest ich niedostosowanie do potrzeb seniorów. Nowa generacja mediów jest dla nich zbyt skomplikowana w obsłudze. Interfejs opisywany poprzez specjalistyczne słownictwo, często obce seniorom. Brak możliwość usprawnień, np.: zwiększenia kontekstu, powiększenia czcionki, dostosowania strony internetowych do programów czytających ich zawartość. Wiele osób po 60. roku życia ma problemy z upośledzeniem ostrości widzenia, pogorszeniem widzenia przy słabym oświetleniu czy ograniczeniem pola widzenia. Ich analizatory wzrokowe, słuchowe, węchowe, dotyku, kinestetyczne ulegają osłabieniu, następuje degeneracja połączeń synaptycznych ${ }^{37}$. Producenci sprzętu starają się wychodzić naprzeciwko potrzebom ludzi starszych i coraz częściej oferują np. telefony o ograniczonej liczbie funkcji, z większą czcionką na wyświetlaczu czy dużymi przyciskami. W niwelowaniu ograniczeń wynikających z problemów ze wzrokiem pomagają także specjalne urządzenia, aplikacje lub oprogramowanie dedykowane dla tej grupy wiekowej. Głównymi odbiorcami i użytkownikami nowych technologii są osoby młode i to do nich w głównej mierze producenci kierują swoją ofertę. Zauważalny jest jednak wzrost działań ukierunkowanych na osoby starsze, w których traktowani są oni jako aktywni i świadomi użytkownicy technologii informacyjno-komunikacyjnych. Naprzeciw oczekiwaniom seniorów starają się

37 A. Kowalewska, Wybrane układy i funkcje organizmu człowieka ważne dla procesów uczenia się, [w:] Biomedyczne podstawy ksztatcenia i wychowania, Z. Izdebski, K. Komosińska, A. Kowalewska, B. Woynarowska, Wydawnictwo Naukowe PWN, Warszawa 2010, za: Ł. Tomczyk, Edukacja osób starszych. Seniorzy w przestrzeni nowych mediów, Difin, Warszawa 2015. 
także wychodzić bankowcy i choć nie oferują specjalnych aplikacji mobilnych dla osób starszych, to starają się dostosować swoją ofertę do ich potrzeb, np. mBank powołał specjalną grupę konsultantów, których zdaniem jest wyjaśnienie w przystępny sposób, jak działa aplikacja czy serwis; sieć Orange ma specjalną infolinię dla seniorów; w PKO BP doradcy podczas wizyt informują i pokazują klientom, jak korzystać z serwisu internetowego iPKO i aplikacji mobilnej $\mathrm{IKO}^{38}$.

\section{Zakończenie}

Współczesny człowiek został wdrożony w społeczeństwo techniczne, w którym o jego codziennym funkcjonowaniu i bezpieczeństwie w coraz większym stopniu decydują systemy techniczne ${ }^{39}$. $Z$ jednej strony rozwój techniki, narzędzi informacyjno-komunikacyjnych przyczynia się do podniesienia komfortu życia, ułatwia wykonywanie zadań dnia codziennego, ale z drugiej prowadzi do podziałów, wykluczenia cyfrowego, zepchnięcia na margines życia osób, grup społecznych. Przy braku odpowiedniego wsparcia, edukacji, a przede wszystkim motywacji podziały cyfrowe będą się pogłębiać. Wraz z upływem czasu $\mathrm{w}$ wiek podeszły będą wkraczać osoby, których kompetencje medialne są na wyższym poziomie. Niemniej jednak rozwój techniki będzie przebiegał o wiele szybciej niż zastępowanie pokoleń. Coraz szybszy postęp w dziedzinie techniki, ICT sprawia, że coraz więcej osób w starszym wieku obsługujących narzędzia ICT nie nadąża za ich rozwojem. Dlatego tak ważna jest edukacja $w$ tym zakresie.

${ }^{38}$ M. Bednarek, Zagubiony senior w bankowości mobilnej. Specjalne infolinie w Orange i doradcy w PKO, Wyborcza 2017, 23 czerwca, http:/ / wyborcza.biz/ biznes/ 7,158582,21998635,zagubiony-senior-w-swiecie-bankowosci-mobilnej-specjalne-infoli nie.html [dostęp: 18.06.2018].

${ }^{29}$ P. Sztompka, Socjologia. Analiza społeczeństwa, Wydawnictwo Znak, Kraków 2002, za: Ł. Tomczyk, op. cit. 


\section{Bibliografia}

Ambrosiewicz J., Szylke I., Społeczne, kulturowe $i$ technologiczne uwarunkowania (nie)korzystania $z$ Internetu, [w:] W sieci i poza siecia. Typologia relacji $i$ strategie przystosowawcze wokót cyberprzestrzeni, red. K. Stachura, Wydawnictwo Uniwersytetu Gdańskiego, Gdańsk 2010.

Barani K., Hołda M., Osobowość i jakość życia, a korzystanie z Internetu przez seniorów, [w:] Senior zalogowany, red. B. Szmgielska, Wydawnictwo Uniwersytetu Jagiellońskiego, Kraków 2014.

Bąk A., Jaszczak A., Rzeczywiste kompetencje seniorów w zakresie korzystania z Internetu, [w:] Senior zalogowany, red. B. Szmigielska, Wydawnictwo Uniwersytetu Jagiellońskiego, Kraków 2014.

Bojarska N., Dawidowska M., Zamiast zakończenia. O zróżnicowaniu internetowego krajobrazu, [w:] W sieci i poza siecia. Typologia relacji $i$ strategie przystosowawcze wokót cyberprzestrzeni, red. K. Stachura, Wydawnictwo Uniwersytetu Gdańskiego, Gdańsk 2010.

Dijk J., Społeczne aspekty nowych mediów, Wydawnictwo Naukowe PWN, Warszawa 2010, za: A. Niemczyk, Seniorzy wobec nowych technologii, „Studia Ekonomiczne. Zeszyty Naukowe Uniwersytetu Ekonomicznego w Katowicach" 2016, nr 303.

Gacka J., Polscy seniorzy w sieci: wirtualna złota jesień? Korzystanie przez osoby dojrzałe $z$ internetu i nowych technologii, „Konteksty Społeczne” 1 (9)/2017, s. 84-91.

Gruchoła M., Nowe formy zachowań społecznych wobec i pod wptywem mediów oraz nowych technologii. Analizy porównawcze, „Państwo i Społeczeństwo" 2017, t. XVII, nr 3.

Kowalewska A., Wybrane układy i funkcje organizmu człowieka ważne dla procesów uczenia się, [w:] Z. Izdebski, K. Komosińska, A. Kowalewska, B. Woynarowska, Biomedyczne podstawy ksztatcenia $i$ wychowania, Wydawnictwo Naukowe PWN, Warszawa 2010.

Morbitzer J., Seniorzy w społeczeństwie informacyjnym, [w:] Seniorzy w świecie nowych technologii. Implikacje dla praktyki edukacyjnej oraz rozwoju społeczeństwa informacyjnego, red. Ł. Tomczyk, A. Wąsiński, „Biblioteka Gerontologii Społecznej” 2013, nr 1-2.

Mucha M., Demograficzne uwarunkowania konsumpcji - seniorzy na rynku dóbr i ustug w Polsce, „Prace Naukowe Uniwersytetu Ekonomicznego we Wrocławiu” 2017, nr 501.

Small G., Vorgan G., iMózg. Jak przetrwać technologiczna przemianę wspótczesnej umystowości, Vesper, Poznań 2011.

Stachura K., Wymiary cyfrowych nierówności. Uwagi o problemie technologicznej nieobecności, w: Nieobecność społeczna. W poszukiwaniu sensów i znaczeń, red. Z. Galor, B. Goryńska-Bittner, Wyższa Szkoła Nauk Humanistycznych i Dziennikarstwa, Poznań 2012. 
Sulik M., Jesień życia kobiety - aspekty edukacyjne, [w:] Edukacja wobec starości - tradycja i wspótczesność, red. A. Stopińska-Pająk, Uniwersytet Śląski, Katowice 2009.

Szpunar M., Senior w środowisku nowych mediów, w: Seniorzy w świecie nowych technologii. Implikacje dla praktyki edukacyjnej oraz rozwoju społeczeństwa informacyjnego, red. Ł. Tomczyk, A. Wąsiński, „Biblioteka Gerontologii Społecznej” 2013, nr 1-2. Sztompka P., Socjologia. Analiza społeczeństwa, Wydawnictwo Znak, Kraków 2002.

Tomczyk Ł., Edukacja osób starszych. Seniorzy w przestrzeni nowych mediów, Difin, Warszawa 2015.

Wasilewska K., Zaangażowanie seniorów w zakresie technologii informacyjno-komunikacyjnych na tle umiejętności młodszego pokolenia. „Zeszyty Naukowe Wydziału Elektroniki i Informatyki Politechniki Koszalińskiej” 2015, nr 7.

Zalega T., Konsumpcja osób starszych w Polsce, "Nierówności Społeczne a Wzrost Gospodarczy" 2015, nr 42 (2/2015).

\section{Źródła internetowe}

Batorski D., Technologie $i$ media $w$ domach $i w \dot{z y c i u, ~[w:] ~ D i a g n o z a ~ s p o ł e c z n a ~} 2015$. Warunki i jakość życia Polaków, red. J. Czapiński, T. Panek, Rada Monitoringu Społecznego, Warszawa 2015, s. 373-395, http://www.diagnoza.com/pliki/ raporty/Diagnoza_raport_2015.pdf [dostęp: 13.06.2018].

Bednarek M., Zagubiony senior w bankowości mobilnej. Specjalne infolinie w Orange i doradcy w PKO, „Wyborcza” 2017, 23 czerwca, http:/ / wyborcza.biz/biznes/7,158 582,21998635,zagubiony-senior-w-swiecie-bankowosci-mobilnej-specjalne-infoli nie.html [dostęp: 18.06.2018].

Ferry M., Baker R., Strategie regionalne a starzenie się społeczeństwa, Komitet Regionów-Age Concern England, Bruksela 2006, http://ec.europa.eu/regional_poli cy/archive/conferences/demographicchallenge_jan07/doc/presentations/age proofing_toolkit_pl.pdf [dostęp: 21.05.2018].

Human Capital - Digital Inclusion and Skills, Digital Economy and Society Index Report 2018, Human Capital, http:/ / ec.europa.eu/newsroom/dae/document.cfm? doc_id=52247 [dostęp: 12.10.2018].

Ludność. Stan i struktura oraz ruch naturalny w przekroju terytorialnym w 2017 r. Stan w dniu 31 XII, Główny Urząd Statystyczny, Warszawa 2018, https://stat.gov. pl/obszary-tematyczne/ludnosc/ludnosc/ludnosc-stan-i-struktura-oraz-ruchnaturalny-w-przekroju-terytorialnym-w-2017-r-stan-w-dniu-31-xii,6,23.html [dostęp: 21.05.2018].

Polańska K, Nierówność cyfrowa jako pochodna dyfuzji Internetu, „Studia Informatica” nr 29, "Zeszyty Naukowe Uniwersytetu Szczecińskiego" 2012, nr 721, s. 235-247, http://www.wneiz.pl/nauka_wneiz/studia_inf/29-2012/si-29-235.pdf [dostęp: 10.06.2018]. 
Palczyńska M., Wykorzystanie technologii informacyjno-komunikacyjnych, [w:] Umiejętności Polaków - wyniki Międzynarodowego Badania Kompetencji Osób Dorostych (PIAAC), IBE, Warszawa 2013, s. 117-136, http://eduentuzjasci.pl/images/sto ries/publikacje/ibe-raport-PIAAC-2013.pdf [dostęp: 1.06.2018].

Społeczeństwo informacyjne w Polsce w 2017 r., Główny Urząd Statystyczny, Warszawa 2017, https://stat.gov.pl/download/gfx/portalinformacyjny/pl/default aktualnosci/5497/2/7/1/spoleczenstwo_informacyjne_w_polsce_w_2017.pdf [dostęp: 13.06.2018].

Społeczeństwo informacyjne w Polsce. Wyniki badan statystycznych $z$ lat 2013-2017, Główny Urząd Statystyczny, Warszawa-Szczecin 2017, http:/ /stat.gov.pl/obsza ry-tematyczne/nauka-i-technika-spoleczenstwo-informacyjne/spoleczenstwoinformacyjne/spoleczenstwo-informacyjne-w-polsce-wyniki-badan-statystycz nych-z-lat-2013-2017,1,11.html [dostęp: 13.06.2018].

Tomczyk Ł., Seniorzy w świecie nowych mediów, „E-mentor” 2010, nr 4 (36), s. 52-61, http://www.e-mentor.edu.pl/artykul/index/numer/36/id/776 [dostęp: 1.06.201]. 